\title{
Biochemical Studies on the Embryonic Development of the Mammalian Inner Ear in Organ Culture***
}

\author{
Matti Anniko, ${ }^{1,2}$, Hans Nordemar ${ }^{1,2}$, Marie-Louise Spångberg ${ }^{2}$, \\ and Jochen Schacht ${ }^{2,3}$ \\ ${ }^{1}$ Department of Otolaryngology, Karolinska sjukhuset, S-104 01 Stockholm, Sweden \\ ${ }^{2}$ King Gustaf V Research Institute, Karolinska Institutet, S-104 01 Stockholm, Sweden \\ ${ }^{3}$ Kresge Hearing Research Institute, University of Michigan, Ann Arbor, MI 48109, USA
}

Zusammenfassung. Diese Arbeit vergleicht die embryonale Entwicklung von Adenylatzyklase und die Markierung von Phospholipiden im Innenohr in vivo und in vitro. Die Innenohranlage von CBA-Mäusen wurde am 16. Tag der Entwicklung explantiert und 3-12 Tage in vitro kultiviert. Die Gestationszeit in vivo beträgt 21 Tage.

Während der ersten Woche wächst das Innenohr in vitro nur wenig, gemessen am Proteingehalt. Während der gleichen Zeit erhöht sich der Proteingehalt des Labyrinthes in vivo etwa dreifach.

Die Aktivität der Adenylatzyklase ist vergleichbar in vivo und in vitro bis zum 19. Tag der Entwicklung. Danach übersteigt die spezifische Aktivität des Enzymes in vitro die Aktivität in vivo um das drei- bis fünffache, was auf einen Mangel an Kontrollmechanismen schließen läßt.

Phospholipide werden mit ${ }^{32} \mathrm{P}$ in vivo und in vitro qualitativ ähnlich markiert, obwohl auch hier quantitative Unterschiede bestehen.

Nach dieser Untersuchung scheint die Bedeutung der Organkultur für Entwicklungsstudien auf die Zeit vor der Geburt beschränkt zu sein.

Schlüsselwörter: Innenohr - Embryonale Entwicklung - Organkultur Vergleich in vivo/in vitro - Biochemie - Protein - Adenylatzyklase Phospholipide

Summary. Adenylate cyclase activity and phospholipid labeling were compared during embryonic development of the mouse inner ear in vivo and in vitro. Inner ears were explanted on the 16th gestational day and cultured in vitro for 3-12 days. The gestation time in vivo is 21 days.

* Supported by grants from Karolinska Institutet, The Foundation Tysta Skolan, The Torsten and Ragnar Söderberg Foundation and The Swedish Medical Research Council (12X-720) (Matti Anniko and Hans Nordemar). Also supported by research grant NS-12881, Program Project Grant NS-05785, and a Senior International Fellowship (FO6-TW00290) of the Fogarty International Center, National Institute of Health (Jochen Schacht)

** Presented at the 17th Workshop on Inner Ear Biology in Stockholm, June 23-25, 1980

Offprint requests to: Dr. H. Nordemar (address see above) 
During the 1st week in vitro there is very little growth of the inner ear with regard to total protein content. In contrast, the labyrinth increases its protein content threefold during the corresponding period of time in vivo.

The activity of adenylate cyclase develops parallel in vivo and in vitro until the 19th gestational day whereafter the specific activity of the enzyme in vitro surpasses that of the enzyme in vivo three- to fivefold suggesting a lack of control mechanisms in organ culture. Phospholipids are labeled by ${ }^{32} \mathrm{P}$ in an essentially similar quantitative relationship in vivo and in vitro, while some quantitative differences exist.

According to the present study the usefulness of the organ culture for the investigation of inner ear development appears limited to a culture period corresponding to an age prior to birth.

Key words: Inner ear - Embryonic development - Organ culture - In vivo/in vitro comparison - Biochemistry - Adenylate cyclase - Phospholipids - Protein

\section{Introduction}

Success in the growth in vitro of the embryonic mammalian inner ear was reported by Van De Water and Ruben (1971), who established an organ culture technique that led to morphogenesis in $90 \%$ of the explants already with otocysts of the 12th gestational day. Subsequently, studies of the developing otocyst in organ culture included quantification of its cytodifferentiation (Van De Water and Ruben 1973), fate mapping ( $\mathrm{Li}$ et al. 1976), determination of the influence of the statoacoustic ganglion on the growing otocyst (Van De Water 1976; Anniko et al. 1979) and culture of the mouse labyrinth of the 16th gestational day as a model for pre- and post-partum development (Anniko et al. 1978). Cytodifferentiation at the cellular and subcellular levels occurs parallel in vivo and in vitro until an age equivalent to birth (Anniko et al. 1979) whereafter differencies in the morphological maturation become evident (Anniko 1980; Anniko and Nordemar 1980).

While the morphological development of the mammalian inner ear in vitro thus seems well documented, corresponding physiologic or biochemical studies are lacking. The aim of the present study is to assess whether the organ culture of the mouse inner ear anlage of the 16th gestational day can also serve as a biochemical model for pre- and post-partum development. We selected two biochemical parameters, adenylate cyclase activity and phospholipid labeling, and compared their in vivo and in vitro development.

Adenylate cyclase is an enzyme which may be important in the regulation of cochlear fluid and electrolyte balance, e.g., in the maturation of endolymph (Bagger-Sjöbäck et al. 1980; Anniko and Schacht, in prep.). Phospholipids were selected as general constitutions of membranes and because of the possible importance of polyphospoinositides for the susceptibility of the mature inner ear to ototoxic damage by aminoglycosides (Schacht 1979; Lodhi et al. 1980). 


\section{Material and Methods}

The CBA/CBA mouse was used in both the in vivo and the in vitro experiments. The gestational period is 21 days.

\section{In Vivo Material}

Inner ears from fetuses and newborn mice were dissected and collected in $0.32 \mathrm{M}$ sucrose $/ 1 \mathrm{mM}$ Tris-Cl, pH 7.6.

\section{In Vitro Material}

Inner ears were explanted on the 16th gestational day and cultured 3-12 days in vitro, i.e., to an age corresponding to 7 days after birth (DAB) as a maximum. Organ culture was maintained in Neuman and Tytell's serumless medium supplemented with $15 \%$ fetal calf serum and $1 \%$ L-glutamine. Incubation took place at $37 \pm 0.2^{\circ} \mathrm{C}$ in air atmosphere with the addition of $5 \% \mathrm{CO}_{2}$ at maximal humidity. Antibiotics or antimycotics were not added. The nutrient solution was renewed every $3 \mathrm{rd}$ day. The $\mathrm{pH}$ was kept constant at 7.2 \pm 0.1 (Anniko et al. 1979).

About half of the labyrinths were divided into a cochlear and a vestibular part at explantation (Anniko et al. 1978). Specimens that had been kept intact during organ culture were divided into these two parts after the culture period immediately prior to the biochemical analyses.

\section{Biochemical Assays}

Details of the biochemical assays will be described elsewhere (Anniko and Schacht, in prep.). For radioactive labeling intact otocysts were incubated in a modified Ringer's solution containing $20 \mathrm{mM}$ acetate and $30 \mathrm{mM}$ glucose as energy sources, $25 \mathrm{mM}$ Tris- $\mathrm{Cl}(\mathrm{pH} 7.4)$ and $60 \mu \mathrm{Ci}(0.1 \mathrm{mM})$ ${ }^{32} \mathrm{P}$-orthophosphate, final volume, $150 \mu \mathrm{l}$. At the end of the incubation, otocysts were transferred to acidified chloroform-methanol, homogenized, and lipids extracted and separated by thin-layer chromatography (Schacht 1978).

For adenylate cyclase assays, otocysts were homogenized in $0.32 \mathrm{M}$ sucrose $/ 1 \mathrm{mM}$ tris-Cl, $\mathrm{pH}$ 7.6. Approximately 10-40 $\mu \mathrm{g}$ of protein were incubated in $100 \mathrm{mM}$ Tris- $\mathrm{Cl}(\mathrm{pH} \mathrm{7.6)}, 0.2 \mathrm{mM}$ isobutyl-methyl-xanthine, $4 \mathrm{mM} \mathrm{MgCl}, 2 \mathrm{mM} \mathrm{ATP,} 0.1 \%$ bovine serum albumine, and $100 \mathrm{mM}$ sucrose (from the added homogenate), total volume, $100 \mu$ l. An ATP-regenerating system was not necessary as assays were linear for both protein concentrations and time. Incubations were terminated with $25 \mu 10 \%$ trichloroacetic acid, centrifuged, and the supernatant passed over Dowex $50\left(\mathrm{H}^{+}\right)$(Steiner 1974) and analyzed for cyclic AMP by radioimmunoassay (Becton-Dickinson, Orangeburg, NY, USA).

The protein content was determined according to Lowry et al. (1951)

\section{Results}

From the 16th gestational day to $2 \mathrm{DAB}$, the otocyst was growing in vivo at an almost constant rate, increasing its protein content three- or fourfold in both the vestibular and cochlear parts (Fig. 1). In contrast to this, there was little or no growth of these structures in organ culture.

In vivo, the specific activity of adenylate cyclase increased at the 19 th gestational day and reverted to a lower level for the subsequent period measured (Fig. 1 and Table 1). In culture, the increase at the 19th gestational day was also 


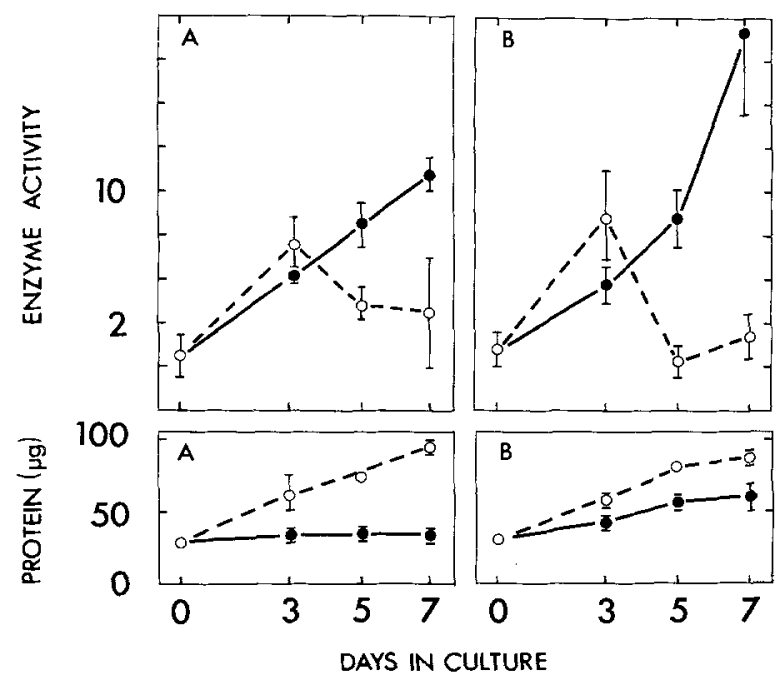

Fig. 1. Protein content and adenylate cyclase activity of cultured otocysts. Otocysts were explanted on day 16, maintained in culture and assayed 3,5, and 7 days after explantation (closed circles and solid lines). In vivo development (open circles and broken lines) is shown for comparison: days 0,3 , 5 correspond to the $16 \mathrm{th}, 19 \mathrm{th}$, and 21 st gestational days, respectively; day 7 to $2 \mathrm{DAB}$ in vivo. Adenylate cyclase activity is expressed as pmol cAMP formed $\cdot \mathrm{min}^{-1} \cdot \mathrm{mg}$ protein ${ }^{-1} \cdot A$ Cochlea; $B$, Vestibular part of the labyrinth

Table 1. Adenylate cyclase in post natal inner ears

\begin{tabular}{llrcc}
\hline Organ & Age & $\begin{array}{c}\text { Protein } \\
(\mu \mathrm{g})\end{array}$ & \multicolumn{2}{c}{ Adenylate cyclase activity } \\
\cline { 5 - 5 } & & 110 & 5.9 & Control \\
\hline Cochlea in vivo & $6 \mathrm{DAB}$ & 20 & 12.0 & 42.5 \\
Cochlea in vitro & 12 days in culture & 132 & 2.9 & 14.6 \\
$\begin{array}{l}\text { Vestibular half of } \\
\text { labyrinth in vivo }\end{array}$ & 6 DAB & 28 & 12.1 & 48.9 \\
$\begin{array}{l}\text { Vestibular half of } \\
\text { labyrinth in vitro }\end{array}$ & 12 days in culture & & & \\
\hline
\end{tabular}

Homogenates of otocysts were assayed for adenylate cyclase as described in "Methods". Otocysts were taken from mice 6 days after birth or from explants (at 16th gestational day) maintained in culture for 12 days, i.e., corresponding to an age $7 \mathrm{DAB}$. Adenylate cyclase activity is expressed as pmol cAMP formed $\cdot \mathrm{min}^{-1} \cdot \mathrm{mg}^{-1}$ protein. "+GMP-PNP" indicates activity in the presence of $50 \mu \mathrm{M}$ guanylyl immidodiphosphate

observed but thereafter, activity was further increasing (Fig. 1) and maintained at a high level for at least 12 days in vitro, i.e., to an age corresponding to 7 DAB (Table 1). The same degree of stimulation by GMP-PNP is seen in both in vivo and cultured preparations (Table 1).

Lipid labeling in otocysts growing in vivo and in culture demonstrated essentially the same qualitative pattern. The major quantitative difference 
Table 2. Labeling of phospholipids in inner ears grown in vivo and in culture

\begin{tabular}{llccccc}
\hline Organ & Age & \multicolumn{3}{c}{ Labeled lipids (\% of total) } \\
\cline { 2 - 6 } & & PhIP & PhIP & PhA $/ \mathrm{PhC}$ & $\mathrm{PhE}$ \\
\hline $\begin{array}{l}\text { Cochlea in vivo } \\
\text { Cochlea in vitro }\end{array}$ & $2 \mathrm{DAB}$ & 14 & 10 & 42 & 30 & 4 \\
$\begin{array}{l}\text { Vestibular half of } \\
\text { labyrinth in vivo }\end{array}$ & $2 \mathrm{DAB}$ & 9 & 9 & 39 & 39 & 4 \\
$\begin{array}{l}\text { Vestibular half of } \\
\text { labyrinth in vitro }\end{array}$ & 7 days in culture & 11 & 10 & 44 & 32 & 3 \\
\hline
\end{tabular}

Intact otocysts were incubated for $30 \mathrm{~min}$ at $37^{\circ} \mathrm{C}$ as described in "Methods". Numbers are averages of two incubations with two otocysts each. Abbreviations: $P h A / I$, phosphatidic acid and phosphatidylinositol; $P h C$, phosphatidylcholine; $P h E$, phosphatidylethanolamine; $P h I P, P h I P_{2}$, phosphatidylinositol phosphate, -bisphosphate

seemed a decrease of labeled acidic lipids (phosphatidic acid, phosphatidylinositol, -phosphate, bisphosphate) and an increase of labeled phosphatidyl choline in the in vitro specimens.

\section{Discussion}

The morphogenesis of the inner ear in vivo is largely completed on the 16th gestational day and followed by a period of enlargement of the organ parallel with cytodifferentiation in both the vestibular organs and the cochlea.

According to the present study there is very little growth of the inner ear in culture, either when the explant was divided into a vestibular and a cochlear part or when kept intact during the in vitro period. The reason for the lack of growth of the 16th gestational day explant despite its cytodifferentiation in vitro remains obscure. In comparison, explantation of the inner ear at the otocyst stage (11th-13th gestational days) does result in growth of volume, morphogenesis, and histogenesis. However, although the general features of such early otocysts develop in accordance with the inner ear in vivo these otocysts rarely reach complete coiling or mature size during in vitro conditions.

The activity of adenylate cyclase develops parallel in vivo and in vitro until the 19th gestational day whereafter obvious differencies occur. At birth the specific activity is considerably higher in in vitro specimens than in those developed in vivo in both the cochlear and the vestibular parts of the labyrinth. This discrepancy remains during the early post natal period where day 7 after birth was the last one to be assayed in culture. At this stage, the gross morphology of the organ is still preserved but a disintegration of hair cells is often found.

Considering the total enzymatic activity per otocyst (rather than the specific activity per milligram of protein), the lack of growth of the cultured specimens eventually becomes the major determinant in this comparison. At the latest 
stage (Table 1) there is less total activity in cultured otocysts than in those grown in vivo. Yet 7 days after explantation the in vitro specimens surpass the in vivo specimens even in total activity. We cannot conclude from these experiments whether such fluctuations are due to alterations of enzyme synthesis or enzyme activation. The response to the GTP-analog, GMP-PNP (guanylyl imidodiphosphate), appears unchanged in culture.

Phospholipid labeling shows less dramatic differences between the two systems: the same lipids are labeled in an essentially similar quantitative relationship. The presence of polyphosphoinositides in otocysts in vivo and in culture may be of particular importance. Previously, correlations between polyphosphoinositide metabolism and ototoxicity had been demonstrated for the adult guinea pig (Stockhorst and Schacht 1977; Lodhi et al. 1980). The organ culture may thus serve as a suitable model for morphological and biochemical studies of aminoglycoside ototoxicity. The fact, however, that some quantitative differences exist between the labeling of cultured and otocysts developed in vivo again demonstrates that the two systems are not fully comparable.

The lack of some control mechanisms in organ culture, which is evident in this biochemical study, had also been suggested by Anniko (1980) on the basis of morphological findings. The tectorial membrane is formed primarily prior to birth with maximal secretion from the interdental cells occurring around the 18th gestational day in vivo. When explants of otocysts of the 16th gestational day were cultured, a rather constant secretion from the interdental cells was observed even in cultures corresponding to a post natal age. Furthermore, the extruded material did not aggregate to a complete tectorial membrane.

While the organ culture of the inner ear has been used rather successfully for morphological studies of development, our present finding indicate that this usefulness may be limited to periods prior to birth. Biochemical development in culture does not parallel that in vivo and large discrepancies exist post natally. Studies, therefore, on the biochemistry of the cultured otocyst or its post natal development require careful comparison to the organ in vivo.

Conversely, biochemical measurements may provide sensitive parameters if we attempt to manipulate organ cultures in order to achieve a longer parallel development to the inner ear in vivo.

\section{References}

Anniko M, Van De Water TR, Nordemar H (1978) Organ culture of the 16th gestation day mouse labyrinth. A model suggestion for pre- and post-partum development. Acta Otolaryngol (Stockh) 86:52-55

Anniko M, Nordemar H, Van De Water TR (1979) Embryogenesis of the inner ear. I. Development and differentiation of the inner ear. I. Development and differentiation of the mammalian crista ampullaris in vivo and in vitro. Arch Otorhinolaryngol (NY) 224:285-299

Anniko M (1980) Embryogenesis of the inner ear. III. Formation of the tectorial membrane in vivo and in vitro. Anat Embryol (Berl) 160:301-313

Anniko M, Nordemar H (1980) Embryogenesis of the inner ear. IV. Post-natal maturation of the secretory epithelia of the inner ear in correlation with the elemental composition in the endolymphatic space. Arch Otorhinolaryngol (NY) 229:281-288 
Bagger-Sjöbäck D, Filipek CS, Schacht J (1980) Characteristics and drug responses of cochlear and vestibular adenylate cyclase. Arch Otorhinolaryngol (NY) 228:217-222

Li CW, Van De Water TR, Ruben RJ (1976) In vitro study of fate mapping of the mouse otocyst. Trans Am Acad Ophthalmol Otolaryngol 82:273-280

Lodhi S, Weiner ND, Mechigian I, Schacht J (1980) Ototoxicity of aminoglycosides correlated with their action on monomolecular films of polyphosphoinositides. Biochem Pharmacol 29: $597-601$

Lowry OH, Rosebrough NJ, Farr AL, Randall RJ (1951) Protein measurement with the Folin phenol reagent. J Biol Chem 193:265-275

Schacht J (1978) Purification of polyphosphoinositides by chromatography on immobilized neomycin. J Lipid Res 19: 1063-1067

Schacht $J$ (1979) Isolation of an aminoglycoside receptor from guinea pig inner ear tissues and kidney. Arch Otorhinolaryngol (NY) 224:129-134

Steiner AL (1974) Assay of cyclic nucleotides by radioimmunoassay methods. In: Harman JG, O'Malley BW (eds) Methods in enzymology, vol 38. Academic Press, New York, pp 96-105

Stockhorst E, Schacht J (1977) Radioactive labeling of phospholipids and proteins by cochlear perfusion in the guinea pig and the effects of neomycin. Acta Otolaryngol (Stockh) $83: 401-409$

Van De Water TR, Ruben RJ (1971) Organ culture of the mammalian inner ear. Acta Otolaryngol (Stockh) 71:303-312

Van De Water TR, Ruben RJ (1973) Quantification of the in vitro development of the mouse embryo inner ear. Ann Otol Rhinol Laryngol [Suppl 3] 82: 19-21

Van De Water TR (1976) Effects of removal of the statoacoustic ganglian complex upon the growing otocyst. Ann Otol Rhinol Laryngol [Suppl 33] 85:1-32

Received August 14, 1980/Accepted February 6, 1981 